\title{
Mutations of the thyroid peroxidase gene in Chinese siblings with congenital goitrous hypothyroidism
}

\author{
Mutações no gene da peroxidase da tireoide em irmãos \\ chineses com hipotireoidismo congênito com bócio
}

Shao-Gang $\mathrm{Ma}^{\prime}$, Xiao-Juan $\mathrm{Wu}^{1}$, Hong Liu', Wei Xu', Le He

'Department of Endocrinology and Metabolism, Huai'an Hospital of Xuzhou Medical College, Huai'an, China

Shao-Gang Ma designed the study and wrote the manuscript. Xiao-juan Wu, Hong Liu, Wei Xu, and Le He provided and analyzed the data
Correspondence to: Shao-Gang Ma South Huaihai Road, 62 223002 - Huai'an, China shaogangma@yahoo.com.cn

Received on Nov/24/2011 Accepted on Aug/19/2012

\begin{abstract}
Objectives: To investigate thyroid peroxidase gene (TPO) mutations in a Chinese siblings with congenital goitrous hypothyroidism (CGH). Subjects and methods: The proband, his sister, and their parents were enrolled. All subjects underwent clinical examination and laboratory tests. Mutation screening of the TPO gene was performed by sequencing fragments amplified from extracted genomic DNA. Results: The siblings were diagnosed as CGH with neurodevelopmental deficits. Two compound heterozygous inactivating mutations were found in the two patients: a frameshift mutation between positions 2268 and 2269 (c.2268-2269 insT) and a missense mutation at c. $2089 \mathrm{G}>\mathrm{A}$ (p.G667S) of the TPO gene. Their parents, with normal thyroid hormone levels, were heterozygous for mutations c.2268-2269 ins T and c.2089 G>A, respectively. The polymorphisms of c.1207 G>T, c. $1283 \mathrm{G}>\mathrm{C}$, and c.2088 C>T were detected in the family. Conclusions: CGH of the Chinese siblings was due to the TPO gene mutations (c.2268-2269 insT and c.2089 G>A). Arq Bras Endocrinol Metab. 2012;56(9):614-7
\end{abstract}

Keywords

Congenital hypothyroidism; thyroid peroxidase gene; mutation; pedigree

\section{RESUMO}

Objetivos: Investigar mutações no gene da peroxidase da tireoide (TPO) em irmãos chineses com hipotireoidismo congênito com bócio (HCB). Sujeitos e métodos: O probando, sua irmão e seus pais foram analisados. Todos os sujeitos passaram por exames clínicos e laboratoriais. $A$ análise para mutações do gene TPO foi feita por meio de sequenciamento de fragmentos amplificados do DNA genômico extraído. Resultados: Os irmãos foram diagnosticados com HCB e déficits de desenvolvimento neurológico. Duas mutações compostas, heterozigotas, inativadoras foram observadas nos dois pacientes: uma mutação frameshift entre as posições 2268 e 2269 (c.2268-2269 insT), e uma mutação missense em c.2089 G>A (p.G667S) do gene TPO. Os pais apresentaram níveis normais de hormônios da tiroide e eram heterozigotos para mutações em c.2268-2269 insT e c.2089 G>A, respectivamente. Foram detectados polimorfismos de c.1207 G>T, c.1283 G>C, e c.2088 C>T na família. Conclusões: O HCB dos irmãos chineses foi devido a mutações no gene TPO (c.2268-2269 insT e c.2089 G>A). Arq Bras Endocrinol Metab. 2012;56(9):614-7

Descritores

Hipotireoidismo congênito; gene da peroxidase da tireoide; mutação; pedigree

\section{INTRODUCTION}

$\mathrm{C}$ ongenital hypothyroidism $(\mathrm{CH})$ is one of the most frequent causes of mental retardation in children, with a prevalence of $1: 3,000-4000$ in newborns (1). Primary newborn screening for $\mathrm{CH}$ has been adopted by most countries, and a newborn $\mathrm{CH}$ screening program was initiated in metropolises of China in the 1980s (2,3). However, while some mutations causing $\mathrm{CH}$ have been identified in a few patients, the molecular cause of $\mathrm{CH}$ in the majority of cases remains 
unknown. To our knowledge, there are few data collected in the Chinese mainland (4-7). It is estimated that $15 \%$ of $\mathrm{CH}$ cases occur as a consequence of defects in thyroid hormone biosynthesis, in which human thyroid peroxidase (TPO) plays an essential role (8). TPO defects are believed to be the most prevalent causes of congenital goitrous hypothyroidism (CGH) (9).

The human TPO gene is located on the chromosome 2p25. It consists of 17 exons and encodes 933 amino acids $(10,11)$. Most cases of CGH are a result of defective thyroid hormone synthesis. Inactivating mutations form the molecular basis of a specific subtype of $\mathrm{CH}$ : thyroid dyshormonogenesis due to an iodide organification defect (IOD). IOD is characterized by reduced ability of the thyroid gland to retain iodide, and is classified as total iodine organification defect (TIOD) or partial iodine organification defect (PIOD) as defined by the perchlorate discharge test $(9,12)$. CH occurs when infants are unable to produce sufficient amounts of thyroid hormone at birth. Mutations in the TPO gene appear to account for the most common cause of IOD and CGH that are inherited in an autosomal recessive manner.

Currently, 61 properly annotated mutations in the TPO gene have been reported. Most of these are missense mutations (9). It is believed that more mutations in the human TPO gene are likely to be reported. In this study, we aimed at detecting the mutation of the TPO gene in a Chinese young man and his older sister with CGH.

\section{SUBJECTS AND METHODS}

\section{Participants}

The sister and brother were born in 1991 and 1995 , respectively, when neonatal screening for $\mathrm{CH}$ had not been introduced in Huai'an, P.R. China $(2,3)$ yet. In 1997, they were diagnosed based on clinical symptoms, thyroid palpation, ${ }^{131}$ I uptake, and blood test data. But the severity of hypothyroidism was greater in the boy than in the girl. Thyroid ultrasound was performed in both patients and their parents. All subjects underwent routine medical check-up and intelligence quotient (IQ) test. The sister and the boy were treated with desiccated thyroid tablets immediately after admission, when the boy was two years old, and the sister was six.

Their parents were not consanguineous and had no common ancestors. They had normal thyroid function. The present study was approved by the Ethics Committee of the hospital, in accordance with the Declaration of Helsinki. Informed consent was obtained from the patients and their parents. Thyroid blood test data and clinical characteristics are shown in table 1.

\section{DNA sample preparation and sequencing}

Genomic DNA was extracted from the participants, including the patients, their parents, and 105 unrelated controls following standard procedures. Each of the 17 exons of the TPO gene, including the splicing regions, was amplified by polymerase chain reaction (PCR). Because exon 8 was too large, it was amplified using two pairs of primers. PCR primers and conditions were described elsewhere (5).

\section{RESULTS}

Neurodevelopment in the boy with congenital hypothyroidism who did not receive early treatment was generally worse than his sister's. The patients had goiter. Thyroid development and palpation were normal in their parents. TPO gene mutations were detected in the patients and their parents (Table 2). Sequencing electropherograms and identification of mutations are shown in figure 1 and table 3, respectively. Direct sequencing indicated that the boy and the girl carried the same compound heterozygous mutations: $\mathrm{G}$ to $\mathrm{A}$ transversion at nucleotide position 2089 in exon 11 (Figure 1A), and

Table 1. Thyroid blood tests and clinical diagnosis of the family at the time of detection of congenital hypothyroidism, in 1997

\begin{tabular}{|c|c|c|c|c|c|}
\hline Clinical diagnosis & Normal range & Son & Daughter & Mother & Father \\
\hline Age (years) & / & 2 & 6 & 31 & 28 \\
\hline Free thyroxine (pmol/L) & $7.91-20.59$ & 1.20 & 2.35 & 14.32 & 15.27 \\
\hline Free triiodothyronine (pmol/L) & $2.92-5.93$ & 0.11 & 0.35 & 4.56 & 5.91 \\
\hline Thyrotropin $(\mu \mathrm{lU} / \mathrm{mL})$ & $0.34-5.44$ & 20.54 & 18.21 & 2.01 & 1.66 \\
\hline Antithyroglobulin antibody (IU/mL) & $0-34$ & 5.3 & 18.4 & 6.5 & 3.7 \\
\hline Thyroid peroxidase antibody (IU/mL) & $0-12$ & 2.0 & 2.2 & 1.2 & 0.9 \\
\hline Thyroid iodine--131 | uptake (\%) & $24 \mathrm{~h}: 20 \%-45 \%$ & 8.3 & 10.2 & 28 & 33 \\
\hline Goiter & / & Goiter & Goiter & Normal & Normal \\
\hline
\end{tabular}


single $\mathrm{T}$ insertion between nucleotide positions 2268 and 2269 (c.2268-2269 insT) in exon 13 (Figure 1B). The transversion mutation results in the replacement of an acidic residue at amino acid position 667 (Gly667Ser, G667S) (13), while the insertion results in a frameshift mutation, leading to a truncated polypeptide of 756 amino acids (4).

Table 2. Clinical and biochemical parameters of the family at the time of study entry, in 2011

\begin{tabular}{lcccc}
\hline Clinical diagnosis & Son & Daughter & Mother & Father \\
\hline Age (years) & 16 & 20 & 46 & 43 \\
Height (cm) & 161 & 152 & 170 & 156 \\
Weight (kg) & 58 & 51 & 73 & 55 \\
Vision & Normal & Normal & Normal & Normal \\
Full scale IQ & 75 & 92 & 101 & 95 \\
\hline
\end{tabular}

Heterozygous mutations were detected in the father and mother. The transversion $(\mathrm{c} .2089 \mathrm{G}>\mathrm{A})$ was detected in the father, while the insertion (c.22682269 ins T) was detected in the mother. The former was derived from her mother and the latter from her father. One hundred and five unrelated controls without thyroid disease were screened by direct sequencing, and none was found to carry either of the two mutations, thus excluding the possibility of polymorphism in Huai'an, China.

Three previously described polymorphisms were also found in the family: Ala373Ser (c.1207 G>T, $\mathrm{TCG} \rightarrow \mathrm{GCG}, \mathrm{Ala} \rightarrow \mathrm{Ser}$ ) (14), Ser398Thr (c.1283 $\mathrm{G}>\mathrm{C}$, AGC $\rightarrow$ ACC, Ser $\rightarrow$ Thr) (14), and Asp666Asp (c.2088 C>T, GAC $\rightarrow$ GAT, Asp $\rightarrow$ Asp) (15) (Table 3). Pedigree analysis showed that the pattern was consistent with autosomal recessive inheritance (Figure l).
Table 3. Mutations and polymorphisms identified in the thyroid peroxidase gene

\begin{tabular}{|c|c|c|c|c|}
\hline $\begin{array}{l}\text { Family } \\
\text { member }\end{array}$ & Exon & $\begin{array}{l}\text { Mutation } \\
\text { position }\end{array}$ & Genotype & $\begin{array}{l}\text { Nature of the } \\
\text { mutation }\end{array}$ \\
\hline \multirow[t]{4}{*}{ Son } & 8 & $1207 \mathrm{G}>\mathrm{T}$ & $\mathrm{T} / \mathrm{T}$ & polym Ala $\rightarrow$ Ser \\
\hline & 8 & $1283 \mathrm{G}>\mathrm{C}$ & $\mathrm{C} / \mathrm{C}$ & polym Ser $\rightarrow$ Thr \\
\hline & 11 & $2089 G>A$ & $\mathrm{G} / \mathrm{A}$ & mutation Gly $\rightarrow$ Ser \\
\hline & 13 & 2268-2269 insT & $\mathrm{TG} / \mathrm{TTG}$ & frameshift \\
\hline \multirow[t]{4}{*}{ Daughter } & 8 & $1207 \mathrm{G}>\mathrm{T}$ & $\mathrm{T} / \mathrm{T}$ & polym Ala $\rightarrow$ Ser \\
\hline & 8 & $1283 \mathrm{G}>\mathrm{C}$ & $\mathrm{C} / \mathrm{C}$ & polym Ser $\rightarrow$ Thr \\
\hline & 11 & $2089 \mathrm{G}>\mathrm{A}$ & $\mathrm{G} / \mathrm{A}$ & mutation Gly $\rightarrow$ Ser \\
\hline & 13 & 2268-2269 insT & $\mathrm{TG} / \mathrm{TTG}$ & frameshift \\
\hline \multirow[t]{4}{*}{ Mother } & 8 & $1207 \mathrm{G}>\mathrm{T}$ & $\mathrm{G} / \mathrm{T}$ & polym Ala $\rightarrow$ Ser \\
\hline & 8 & $1283 G>C$ & $\mathrm{C} / \mathrm{C}$ & polym Ser $\rightarrow$ Thr \\
\hline & 11 & 2088 C>T & $\mathrm{C} / \mathrm{T}$ & polym Asp $\rightarrow$ Asp \\
\hline & 13 & 2268-2269 insT & TG/TTG & frameshift \\
\hline \multirow[t]{3}{*}{ Father } & 8 & $1207 \mathrm{G}>\mathrm{T}$ & $\mathrm{T} / \mathrm{T}$ & polym Ala $\rightarrow$ Ser \\
\hline & 8 & $1283 \mathrm{G}>\mathrm{C}$ & $\mathrm{C} / \mathrm{C}$ & polym Ser $\rightarrow$ Thr \\
\hline & 11 & $2089 G>A$ & $\mathrm{G} / \mathrm{A}$ & mutation Gly $\rightarrow$ Ser \\
\hline
\end{tabular}

\section{DISCUSSION}

Mutation analysis of the TPO gene in CGH patients has been reported in various ethnic populations $(5,9,16)$. It is interesting to note that the compound TPO mutations were identified in the Chinese mainland, demonstrating the heterogeneous nature of TPO mutations among different ethnic groups. In the present study, TPO 2268 insT and Gly667Ser mutations were not unusual $(4,13)$; nevertheless, there were clinical differences related to gender. Delayed diagnosis and treatment may lead to disorders in physical and cognitive development. Neurodevelopmental deficits in congenital hypothyroidism are correlated with the severity of congenital hypothyroidism and time to TSH normalization (17). However, the boy was generally worse than his sister. It is suggested that these compound mutations may have gender differences regarding ethnic groups.
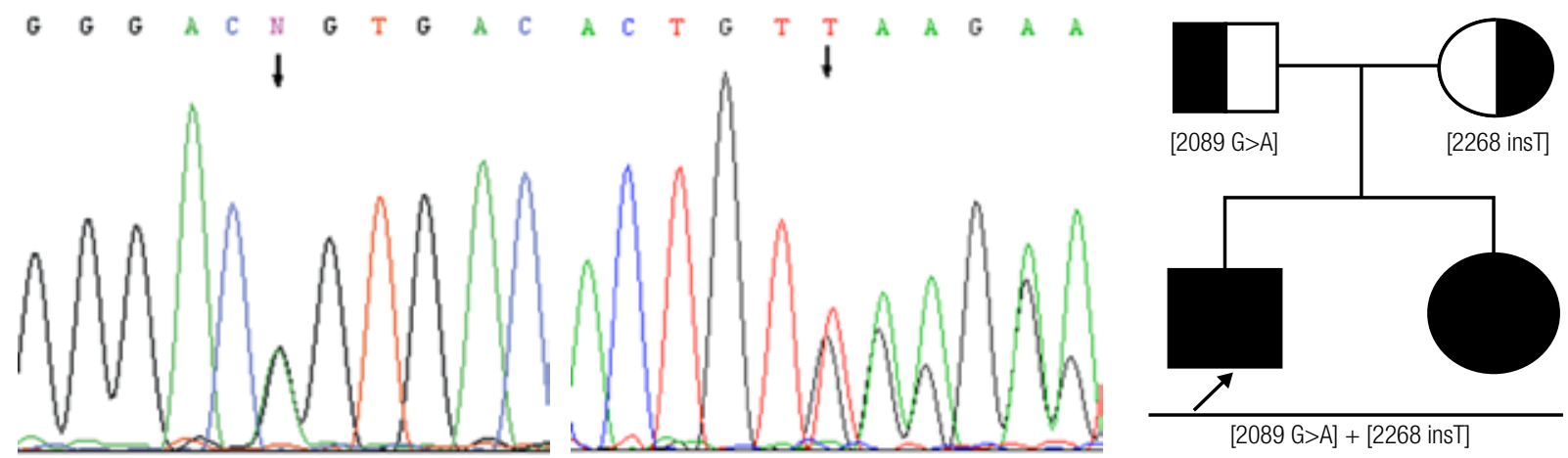

Figure 1. Pedigree and inheritance of the mutations c.2089 G>A and c.2268-2269 insT of the thyroid peroxidase gene. The arrow marks the proband. 
The TPO 2268 insT mutation in exon 13 was previously identified in Taiwan Chinese TIOD patients and was noted to be the most common among these patients ( 12 of 14 studied alleles, $86 \%$ ) (4). In the present study, three out of the four subjects carried this mutation, which leads to a stop codon immediately behind the insertion point, resulting in a truncated polypeptide of 756 amino acids (4).

In the two patients, a missense mutation, 2089 $\mathrm{G}>\mathrm{A}$, was found in exon 11 , which results in an amino acid change from glycine, a nonpolar, hydrophobic residue, to serine (Gly667Ser), a polar and hydrophilic amino acid. Glycine in this position is highly conserved in human and mammalian TPO homologues (13). Umeki and cols. (15) reported a functional exploration of the nearby mutation R665W, which was detected in a patient with severe $\mathrm{CH}$. When mRNAs containing the mutation were transfected into $\mathrm{CHO}-\mathrm{Kl}$ cells, each cell showed faint TPO enzyme activity. TPO proteins encoded by the mutated alleles showed abnormal cellular localization; namely, localization on the plasma membrane was disturbed. Considering the crystal structure of myeloperoxidase, the serine corresponding to glycine 667 in TPO forms part of an $\alpha$-helix that interconnects two locally folded regions (18). Arginine 665 and glycine 667 form the same helical turn. The loss of plasma membrane localization in mutated TPO caused the iodide organification defect, which was diagnosed as $\mathrm{CH}$.

These two mutations and three polymorphisms were prevalent in this pedigree. It is unlikely that CGH disease symptoms of the compound heterozygous patients were caused by the polymorphism or another gene defect because the identified mutations of frameshift and missense mutation coexisted in each patient, while the parents with a single heterozygous mutation and polymorphisms were detected with normal thyroid hormone levels. In addition, the two mutations were not detected in 105 healthy controls.

In conclusion, two TPO gene mutations were identified in the examined subjects. Considering the prevalence of single allele TPO mutations in CGH $(4,9,13)$, the overall prevalence of TPO mutations with possible unidentified cryptic mutations could be even higher in Chinese people. Future studies will be needed to identify undetected TPO mutations.

Disclosure: no potential conflict of interest relevant to this article was reported.

\section{REFERENCES}

1. Jain V, Agarwal R, Deorari AK, Paul VK. Congenital hypothyroidism. Indian J Pediatr. 2008;75(4):363-7.

2. Xue ZX, Yao GY, Qian ZJ, Li ZS. Congenital hypothyroidism: clinical analysis of 30 cases. Chin Med J (Engl). 1987;100(1):49-55.

3. Zhan JY, Qin YF, Zhao ZY. Neonatal screening for congenital hypothyroidism and phenylketonuria in China. World $\mathrm{J}$ Pediatr. 2009;5(2):136-9.

4. Niu DM, Hwang B, Chu YK, Liao CJ, Wang PL, Lin CY. High prevalence of a novel mutation (2268 insT) of the thyroid peroxidase gene in Taiwanese patients with total iodide organification defect, and evidence for a founder effect. J Clin Endocrinol Metab. 2002;87(9):4208-12.

5. Wu JY, Shu SG, Yang CF, Lee CC, Tsai FJ. Mutation analysis of thyroid peroxidase gene in Chinese patients with total iodide organification defect: identification of five novel mutations. J Endocrinol. 2002;172(3):627-35.

6. Yuan ZF, Mao HQ, Luo YF, Wu YD, Shen Z, Zhao ZY. Thyrotropin receptor and thyroid transcription factor-1 genes variant in Chinese children with congenital hypothyroidism. Endocr J. 2008;55(2):415-23.

7. Ma SG, Fang PH, Hong B, Yu WN. The R450H mutation and D727E polymorphism of the thyrotropin receptor gene in a Chinese child with congenital hypothyroidism. J Pediatr Endocrinol Metab. 2010;23(12):1339-44.

8. Rodrigues C, Jorge P, Soares JP, Santos I, Salomão R, Madeira $M$, et al. Mutation screening of the thyroid peroxidase gene in a cohort of 55 Portuguese patients with congenital hypothyroidism. Eur J Endocrinol. 2005;152(2):193-8.

9. Ris-Stalpers $\mathrm{C}$, Bikker H. Genetics and phenomics of hypothyroidism and goiter due to TPO mutations. Mol Cell Endocrinol. 2010;322(1-2):38-43.

10. Kimura S, Kotani T, McBride OW, Umeki K, Hirai K, Nakayama T, et al. Human thyroid peroxidase: complete cDNA and protein sequence, chromosome mapping, and identification of two alternately spliced mRNAs. Proc Natl Acad Sci U S A. 1987;84(16):5555-9.

11. Kimura S, Hong Y-S, Kotani T, Ohtaki S, Kikkawa F. Structure of the human thyroid peroxidase gene: comparison and relationship to the human myeloperoxidase gene. Biochemistry. 1989;28:4481-9.

12. Nascimento AC, Guedes DR, Santos CS, Knobel M, Rubio IG, Medeiros-Neto G. Thyroperoxidase gene mutations in congenital goitrous hypothyroidism with total and partial iodide organification defect. Thyroid. 2003;13(12):1145-51.

13. Avbelj $M$, Tahirovic $H$, Debeljak $M$, Kusekova $M$, Toromanovic $A$, Krzisnik C, et al. High prevalence of thyroid peroxidase gene mutations in patients with thyroid dyshormonogenesis. Eur J Endocrinol. 2007;156(5):511-9.

14. Abramowicz MJ, Targovnik HM, Varela V, Cochaux P, Krawiec L, Pisarev MA, et al. Identification of a mutation in the coding sequence of the human thyroid peroxidase gene causing congenital goiter. J Clin Invest. 1992;90(4):1200-4.

15. Umeki K, Kotani T, Kawano J, Suganuma T, Yamamoto I, Aratake $Y$, et al. Two novel missense mutations in the thyroid peroxidase gene, R665W and G771R, result in a localization defect and cause congenital hypothyroidism. Eur J Endocrinol. 2002;146(4):491-8.

16. Neves SC, Mezalira PR, Dias VM, Chagas AJ, Viana M, Targovnik $\mathrm{H}$, et al. Monoallelic thyroid peroxidase gene mutation in a patient with congenital hypothyroidism with total iodide organification defect. Arq Bras Endocrinol Metabol. 2010;54(8):732-7.

17. Huo K, Zhang Z, Zhao D, Li H, Wang J, Wang X, et al. Risk factors for neurodevelopmental deficits in congenital hypothyroidism after early substitution treatment. Endocr J. 2011;58(5):355-61.

18. Zeng J, Fenna RE. X-ray crystal structure of canine myeloper-oxidase at 3 A resolution. J Mol Biol. 1992;226:185-207. 